STUDIA ROSSICA POSNANIENSIA, vol. XLII: 2017, pp. 45-54. ISSN 0081-6884.

Adam Mickiewicz University Press, Poznań

\title{
ANTONA CZECHOWA SPOJRZENIE NA BIEG HISTORII
}

\author{
CHEKHOV'S VIEW ON THE COURSE OF HISTORY
}

\author{
ANDRZEJ KSENICZ
}

\begin{abstract}
Among the issues, themes and contributions which Anton Chekhov undertook in his works, one may also find the broadly-understood issue of an individual's place in the course of historical events. In this case, and others like it, this writer's opinion stands out among the works of other Russian writers. This is related to the fact that the author of The Steppe is convinced that the individual, and his conscious behaviour, contributes to the behaviour of a group and society. This is in contrast to the reasoning of most Russian writers of those times; however, it proves to be characteristic of Chekhov's thinking.
\end{abstract}

Andrzej Ksenicz, Uniwersytet Zielonogórski, Zielona Góra - Polska, andrzejksenicz@o2.pl

Zacznę od stwierdzenia, iż sam postawiłem się w kłopotliwej sytuacji, ponieważ jeszcze w latach osiemdziesiątych-dziewięćdziesiątych ubiegłego wieku zastanawiałem się, czy autor Mojego życia unika podejmowania zagadnień z kręgu historii i filozofii. Sądzę, że udało mi się wtedy udowodnić obecność kwestii zawierających się $\mathrm{w}$ kręgu obu tych nauk w twórczości pisarza, jego korespondencji, wyrażających się nie tylko poprzez przywoływanie nazwisk znanych filozofów czy badaczy dziejów z różnych epok. Przy okazji stwierdziłem, że kwestia ta była pomijana przez badaczy rosyjskich. Wprawdzie już w 1900 roku ksiądz G. Pietrow dowodził, że mylą się ci, którzy twierdzą, iż pisarza nie interesują sprawy najistotniejsze dla człowieka. Wychodził on od Ewangelii, a swój wywód ilustrował tzw. „krzyczącą rzeczywistością", wskazując przy tym, że już poczynając od Platona mówiono, iż wszystkim należy stawiać jednakowe wymagania i dawać możliwość realizowania ich potrzeb, co odnotowywał on u autora Stepu ${ }^{1}$. Kilka lat później inny autor, również związany z cerkwią, mówił wprost, że Czechow kontynuuje literaturę filozoficzną typu L. Tołstoja i F. Dostojewskiego. Trafnie zauważał też, iż czytając Czechowa, należy wychodzić od filozofii chrześcijańskiej, ale nie posuwał się do głębszej analizy jego tekstów. Trzeba wszakże zgodziś się z takim jego przekonaniem:

1 Zob. Г. П е т р о в, ЕВангелие, как основа жизни, Санкт-Петербург 1900, s. 98-106. 
Итак, общечеловеческий, а по тому самому и философский вопрос, дающий главное содержание творчеству Чехова, есть вопрос о нравственной слабости, бессилии добра в душе среднего человека, благодаря которому сваливается он без борьбы, [...] благодаря которому идеальные стремления не поднимают, а только заставляют бессильно страдать человека $[. . .]^{2}$.

Przez wiele dziesiątek lat uważano jednak Czechowa za autora, który prezentuje realny, źle zbudowany świat i na tym zwykle poprzestaje. Jeszcze $\mathrm{w}$ latach siedemdziesiątych-osiemdziesiątych XX wieku $\mathrm{w}$ byłym ZSRR pisano o autorze Nieciekawej historii jako twórcy, którego nie interesuje historia, jej przebieg. A jeżeli już nawet odnotowywano ten moment, to konstatowano, że pojawia się on u pisarza, jak pisał m.in. I. Gurwicz, jako „powszedniość, a nie historia”. Natomiast same fakty historyczne ujmowane są w jego utworach „w lirycznym komentarzu” 3 .

W latach dziewięćdziesiątych zaczęły pojawiać się nawiązania do przytoczonych tu najwcześniejszych ocen odnoszących się do pisarstwa Czechowa. A. Sobiennikow przypominał, że dla tego twórcy „люди все равны потому, что они люди"4. Podobny sąd o pisarzu wyraził w swej powieści Życie i los (Жизнь и судьба) Wasilij Grossman, ale wtedy nie przebił się on przez oficjalną ocenę Czechowa. Głos ten był zanadto śmiały, aby mógł być przyjęty w radzieckich czasach jako możliwy do zaakceptowania ${ }^{5}$. Pozwolę sobie $\mathrm{w}$ tym miejscu na mały prywatny wtręt. W latach osiemdziesiątych-dziewięćdziesiątych ubiegłego wieku pisałem, że Czechow nie jest pisarzem „rosyjskim”. I to nie z uwagi na to, że zawsze nazywał siebie "chochłem”, ale dlatego, że nie znajdujemy u niego nic z myślenia Tołstoja czy Dostojewskiego o Rosji, Rosjanach ${ }^{6}$. Wydaje się, że dziś potwierdza się to, tak $\mathrm{z}$ mojego punktu widzenia, jak też w rozumieniu Grossmana.

Jedno $\mathrm{z}$ istotniejszych stanowisk $\mathrm{z}$ połowy lat dziewięćdziesiątych ubiegłego wieku prezentuje wypowiedź W. Katajewa, który pisał wprost, iż krytyka nadal "pozostawia pisarza z boku”, jeżeli chodzi o koncepcje filozoficzne $\mathrm{w}$ jego twórczości. Obiegowa ocena $\mathrm{z}$ tamtego okresu brzmi mniej więcej tak: „тонкий художник, но не мыслитель”. Autor artykułu uważa, że pisarz nie jest ontologiem, o czym mówiono już wcześniej, ale że umie on widzieć świat gnozeologicznie: „Таким - редчайшим для Рос-

2 С. Б у л г а к о в, Чехов, как мыслитель, Киев 1905, s. 11.

${ }^{3}$ И. Г у р в и ч, Проза Чехова. (Человек и действительность), Москва 1970, s. 151-152.

4 Zob. A. С о б е н н и к о в, Библейский образ в прозе А. П. Чехова (аксиология и поэтика), [w:] О поэтике А. П. Чехова. Сборник научных трудов, редкол. Г. Чернышова и др., Изд-во Иркутского университета, Иркутск 1993, s. 24-25.

${ }^{5}$ Zob. W. G r o s s m a n, Życie i los, przeł. J. Czech, Warszawa 2011, s. 289-294.

${ }^{6}$ Zob. m.in. A. K s e n i c z, Anton Czechow - nieco inaczej o sobie i innych, [w:] tegoż, Stowiański wielogłos, czyli od Antona Czechowa do Jerzego Harasymowicza, Zielona Góra 1999, s. $5-30$. 
сии гносеологическим художником был Чехов"7. То on powtórzył za Czechowem, że nikt nie zna "absolutnej prawdy", do czego piszący te słowa nawiąże jeszcze w niniejszym tekście.

Wypada teraz zastanowić się i odpowiedzieć na pytanie, co wynika z przywołanych tu sądów dla naszego zamysłu sformułowanego $\mathrm{w}$ temacie artykułu? Jeżeli wyjdziemy od przytoczonej zasady pisarza, to okaże się, że według niego ciągiem wypadków historycznych rządzi przypadek, czasem człowiek oraz jakaś wyższa wola. Aby do tego dojść, należy, jak sądzę, spróbować znaleźć w wypowiedziach pisarza, w jego korespondencji pewne wskazówki, dotyczące zagadnień mieszczących się w szerokim kręgu zagadnienia, jakim jest kwestia filozofii dziejów. Dla autora Czarnego mnicha najważniejsza jest jednostka, jej miejsce na ziemi uświadamiane sobie przez nią samą . Dopiero po takim jednostkowym samouświadomieniu może tworzyć się świadomość biegu wypadków w grupie i, szerzej, w społeczeństwie. Odgłosy takiego rozumowania możemy odszukać w listach Czechowa.

Antropocentryczny Czechowowski porządek świata kazał mu widzieć w jednostce aktywny element, co nie znaczy, że nie może ona godzić się $\mathrm{z}$ pewnym fatalizmem $\mathrm{w}$ jej życiu. Takie myślenie nie było obce autorowi Kameleona, chociaż w swoim postępowaniu wykazywał się dużą siłą woli. Ale przecież, kiedy wiedział już bez cienia wątpliwości, że jest ciężko chory, to do siostry Marii pisał tak:

Скажи матери, что как бы ни вели себя собаки и самовары, все равно после лета должна быть зима, после молодости старость, за счастьем несчастье и наоборот; человек не может быть всю жизнь здоров и весел, его ожидают потери, он не может уберечься от смерти, хотя бы был Александром Македонским, - и надо быть ко всему готовым и ко всему относиться как к неизбежно необходимому, как это ни грустно 9.

Czy było to spowodowane tylko sytuacją, w jakiej postawiło go życie? Sądzę, że nie, ponieważ zawsze kierował się on trzeźwym rozumowaniem z zauważalną niekiedy dozą rezygnacji. Niespełna trzydziestoletni pisarz konstatował:

Bce, что живет на земле, материалистично по ненобходимости. [...] Существа высшего порядка, мыслящие люди - материалистичны тоже по необходимости (П. 3. s. 208).

7 В. К а т а е в, Спор о Чехове: конец или начало?, [w:] Чеховиана. Мелиховские труды и дни, Москва 1995, s. 5-6.

8 Zob. m. in. A. K s e n i c z, Czechowowskie przemiany wewnętrzne, [w:] tegoż, Ścieżkami bohaterów Antona Czechowa, Zielona Góra 2007, s. 173-192.

${ }^{9}$ А. П. Ч е х о в, Полное собрание сочинений и писем в тридияати томах. Письма в двенадияати томах, т. 7, Москва 1974-1983, s. 98. Kolejne cytaty w tekście ze wskazaniem na utwór lub list oraz tom i stronę. 
Pisarz był materialistą $\mathrm{w}$ filozoficznym rozumieniu istnienia świata, do czego odnosił się z charakterystyczną dla niego nutką pesymizmu. Kiedy wszakże taka zdawała się pojawiać, to nie poddawał się jej:

Я верю в отдельных людей. Я вижу спасение в отдельных личностях, [...] чтобы там ни было, наука все продвигается вперед, [...] (П. 3, s. 100-101).

Na zakończenie tej części prezentacji sposobu myślenia pisarza przytoczę jeszcze dwie wypowiedzi autora Mewy, świadczące o jego swoiście filozoficznym podejściu do znanych mu w tym czasie koncepcji w sposobie postrzegania rzeczywistości. W końcu lat dziewięćdziesiątych XIX wieku zainteresowano się F. Nietzschem. Czechow nie byłby sobą, gdyby nie skomentował tego na swój sposób. W jednym $\mathrm{z}$ listów zauważał on:

С таким философом, как Нитче, я хотел бы встретиться где-нибудь в вагоне или на пароходе и проговорить с ним целую ночь. Философию его, впрочем, я считаю недолговременной. Она не столь убедительна, сколь бравурна (П. 6, s. 29).

Nic zatem dziwnego, że do reżysera W. Niemirowicza-Danczenki pisał $\mathrm{z}$ odrobiną sarkazmu, że można narzekać, a nawet obwiniać klimat, środowisko i co jeszcze chcesz, ale: „[...] предоставь обстоятельства их собственному, неумолимому течению, уповая на лучшее будущее" (П. 6, s. 241-242). Sam był przekonany, że wypadki biegną we właściwym kierunku, co potwierdzają inne jego wypowiedzi. Nie możemy ich tu pomieścić, natomiast wskażę choćby takich adresatów jego listów jak I. Orłow czy A. Tarachowski. Do tego drugiego pisał:

Ведь при росте теперешней культурной жизни никто не может поручиться, что для библиотеки не понадобится через 25-40 лет пятиэтажное здание! Театры же учреждения наполовину коммерческие; дайте срок, и они сами начнут расти, как грибы [...] Как в Неаполе, например (П. 8, s. 314).

Podobnie, choć nierzadko jednak inaczej, wygląda spojrzenie pisarza na bieg wypadków, kiedy zagłębimy się w treść jego prozy i dramaturgii. Najogólniej rzecz można by ująć w stwierdzeniu, że znajdziemy tam mniej czy bardziej wprost, zawsze przy tym po Czechowowsku niejednoznacznie zarysowane, postrzeganie biegu dziejów, w którym uczestniczy jednostka, szerzej, grupa społeczna i już raczej rzadko ogólnie rozumiany naród. Aby ten proces zilustrować, oczywiście w jakiejś jego drobnej części, odwołam się do kilku utworów pisarza. Zacznę od dość wczesnego opowiadania Fujarka (С bupenb) z 1887 roku. Wątek utworu wydaje się bardzo prosty, bowiem zasadza się na typowym „spotkaniu w drodze”. Myśliwy, przypominający postać z dobrze znanego utworu I. Turgieniewa, spotyka przypadkiem w czasie wędrówki po okolicy staruszka-pastucha. Opisowi lasu, pola, myśliwego i samego staruszka naddaje autor pewne zastanawiające rysy, które wywołują u czytelnika wrażenie jakiejś niezwykłości czasu i miejsca: 
Утро было нехорошее, пасмурное. С деревьев, окутанных легким туманом, и с папоротника сыпались кпупные брызги, лесная сырость издавала острый запах гнили (С. 6, s. 321).

Postacie myśliwego i pastucha również są wystylizowane, co nadaje im osobliwy charakter. Pierwszy z nich jest rosłym, silnym, wydawałoby się, mężczyzną, ale jego głos, uśmiech i „cała figura” miały w sobie coś „бабье, робкое и смиренное”. Pastuch stoi przed myśliwym: „тощий, в рваной сермяге и без шапки" (s. 321). Już początek rozmowy między nimi wskazuje, jak bardzo poważnie traktują oni to, co zauważyli w przyrodzie. Staruszek ocenia odnotowane zmiany bardzo pesymistycznie: „Все к одному клонится... Добра не жди" (s. 322). Mówi to na podstawie obserwacji przyrody, która jego zdaniem ginie: „Лет двадцать назад, помню, тут и гуси были, и журавли, и утки, и тетерева - туча-тучей. [...] Нынче, брат, волк и лиса в диковинку, а не то что медведь или норка". Swą dość długą tyradę zamyka zdaniem pełnym pesymizmu: „- K худу, паря. Надо думать, к гибели... Пришла пора божьему миру погибать" (s. 323). Sąd swój opiera on na obserwacji tego, co zachodzi w całej okolicy. Jeszcze gorzej jest "z narodem”, który stał się chorowity, słaby, nie chce pracować, chociaż zdaniem pastucha naród jest teraz mądrzejszy. Po takich zabarwionych filozoficznie uwagach rozmówców jeszcze bardziej pesymistycznie zdaje się wyglądać przyroda. Jest jesien, wszystko więdnie, zamiera, co zdaje się zapowiadać brak nadziei na lepsze jutro.

Czy tak myślał sam młody pisarz? Skłonny jestem twierdzić, że nie. Podobnie jak $\mathrm{w}$ innych kwestiach, tak $\mathrm{i} \mathrm{w}$ tej autor pozostawał trzeźwo myślącym obserwatorem. W opublikowanym rok później Stepie (Cmenz), utworze bardzo ważnym w procesie formowania Czechowa-twórcy, znajdujemy inne rozwiązanie dla kwestii biegu wypadków, które obejmują wiele postaci z różnych kręgów społecznych. Charakterystycznym momentem wydaje się to, że wszystkim wydarzeniom i rozważaniom przygląda się i przysłuchuje dziewięcioletni chłopiec, odbywający długą podróż do szkoły. Ten fakt podwaja niejako moment oczekiwania czegoś nowego, zapowiada poznawanie przyszłej szkoły życia. O tym, jakie to życie było i jest, chłopiec dowiaduje się w trakcie podróży. Poznaje „wiele prawd”, których jeszcze nie rozumie, podobnie jak nie rozumie, dlaczego większość starszych ludzi mówi o nieudanym życiu. Jedynym szczęśliwym wydaje się młody chochoł-Ukrainiec, który niedawno ożenił się i chętnie o tym opowiada. Wśród smutnych prawd o życiu, jakie słyszy Jegoruszka, następująca brzmi bardzo pesymistycznie: „Русский человек любит вспоминать, но не любит жить [...]”, ponieważ „мы обижены и оскорблены судьбой” (С. 7, s. 63). To, co jest niewiadomą dla chłopca, czytelnikowi wydaje się nawet banalne, ale rozumie on zarazem, że jest to początek drogi, na której spotkają chłopca rozczarowania, wyzwania i samotność. Nie zaskakuje zatem końcowe pytanie w opowieści: „Какова-то будет жизнь?” (s. 104). 
Pytanie to zdaje się zadawać pisarz, a nie Jegoruszka. Dla pierwszego $\mathrm{z}$ nich, który sam przeszedł trudną szkołę życia, jest ono niezwykle istotne. $\mathrm{W}$ listach pisarza niejednokrotnie pojawia się podobny moment zastanowienia nad złożonością życia człowieka. Takie uwagi na temat myślenia pisarza spotykamy we wspomnieniach ludzi z kręgu jego znajomych ${ }^{10}$. Z obu źródeł dowiadujemy się, że to człowiek odpowiada za to, jak przeżył swoje życie.

Kolejnym, chronologicznie, po Stepie jest opowiadanie Ognie (Огни). Zajmuje ono u twórcy miejsce dość szczególne, z uwagi na podjętą w nim kwestię, a stanowią o tym rozważania na temat roli człowieka w historii i rozwoju naszej cywilizacji. Pozostają one jakby w cieniu głównego wątku, osnutego na historii głównego bohatera i jego nieudanej miłości. Wskazane $\mathrm{w}$ tym miejscu wydaje się przypomnienie sytuacji zarysowanej $\mathrm{w}$ pierwszym z przywołanych przez nas utworów, a mianowicie o tworzeniu przez Czechowa specyficznej atmosfery panującej w jego filozoficznych opowiedaniach. Nie możemy tu zagłębić się specjalnie w jej odtworzenie, natomiast wskażę na jeden choćby moment, który takową buduje:

Высокая, наполовину готовая насыпь, кучи песку и щебня, ямы, разбросанные кое-где тачки, плоские возвышения над землянками, в которых жили рабочие, - весь этот ералаш, выкрашенный потемками в один цвет, придавал земле какую-то странную, дикую физиономию, напоминающую о временах хаоса. [...] Огни были неподвижны. В них, в ночной тишине и унылой песне телеграфа чувствовалось что-то общее. Казалось, какая-то важная тайна была зарыта под насыпью, и о ней знали только огни, ночь и проволоки... (С. 7, s. 105-106).

Jeden z bohaterów opowiadania postrzega teraźniejszość i przeszłość bardzo pesymistycznie. Wygłasza sądy o śmierci. Odeszli tacy jak Szekspir i Darwin, co zatem może czekać zwykłych ludzi? Jego interlokutor i zarazem główny bohater rozumie, że jeżeli wszyscy będziemy tak myśleć, to wtedy: „[...] невозможен никакой прогресс, ни наук, ни искусства, ни само мышление" (s. 112). Zapewne można to przemóc, ale trzeba zająć się pracą, żeby odpędzić takie myśli. Tytułowe ognie pełnią $\mathrm{w}$ utworze naddaną im funkcję. Ogień towarzyszy człowiekowi od momentu oswojenia go przez naszych przodków. W tekście pojawiają się one w specyficznie historycznym, a zarazem cywilizacyjnym kontekście:

- Знаете, на что похожи эти бесконечные огни? Они вызывают во мне представление о чем-то давно умершем, жившем тисячи лет тому назад, о чем-то вроде лагеря амеликитян или филистимлян. Точно какой-то ветхозаветный народ расположился станом и ждет утра, чтобы подраться с Саулом или

10 Zob. А. П. Чехов в воспоминаниях современников, ред. В. Вацуро и др., Москва 1986. 
Давидом. Для полноты иллюзии не хватает только трубных звуков, да чтобы на каком-нибудь эфиопском языке перекликались часовые (s. 107).

Poszerzony nieco wgląd $w$ to opowiadanie uzasadniony jest, jak sądzę, specyficznie Czechowowskimi niedopowiedzeniami związanymi z tajemnicą zagadki życia jednostki, narodu, z jakimi spotykamy się w jego utworach. Nic zatem dziwnego, że ten głęboko cywilizacyjny moment, zasadzający się na chęci odpowiedzi na ową zagadkę życia w jej filozoficznym rozumieniu, również $\mathrm{w}$ tym utworze kończą słowa bohatera, podkreślające zamysł pisarza: „Ничего не разберешь на этом свете!” (s. 140).

Znakomity profesor, europejska sława, bohater opowiadania Nieciekawa historia (Скучная история) to przykład postrzegania życia i historii jako bytu indywidualnego, wpisanego w dość przypadkowy bieg wypadków. Zdaje on sobie sprawę, że przeżył bogate $\mathrm{w}$ osiągnięcia naukowe życie, ale teraz czeka go tylko śmierć. Czuje się osamotniony, odtrącony. Godzi się z tym faktem, a jedyne, co sprawia mu przykrość, to fakt, że nie może powiedzieć młodym, jak mają żyć, aby byli szczęśliwi. Pozostała mu jeszcze wiara w naukę:

Испуская последний вздох, я все-таки буду верить, что наука - самое важное, самое прекрасное и нужное в жизни человека, что она всегда была и будет высшим проявлением любви и что только ею одною человек победит природу и себя (С. 7, s. 263).

Podobnie, na co zwracaliśmy już uwagę, również tutaj mamy ten niezwykły dla bohatera, ale zarazem konieczny moment na zastanowienie się i zrozumienie sytuacji, w jakiej postawiło go życie:

Бывают страшные ночи с громом, дождем и ветром, которые в народе называются воробьиными. Одна точно такая же воробьиная ночь была и в моей жизни... (s. 300).

Wywołuje to u profesora strach przed tym, co będzie dalej. Jeszcze większy niepokój odczuwa jego przybrana córka, która prosi go o radę: „Говорите, что мне делать? [...] Ведь вы умны, образованны, долго жили! Вы были учителем!" Odpowiedź profesora jest porażająco prosta: "- По совести, Катя: не знаю..." (s. 308-309). A zatem znowu niedopowiedzenie, zagadka. Katia pozostaje sama ze swoim pytaniem. Ale, rozumując po Czechowowsku, odpowiedź na nie pada: „Nie wiem”.

Zagadka życia, jego koleje zajmowały pisarza wyjątkowo mocno, przy czym zwykle widział on jednostkę wpisaną w niby codzienne bytowanie, ale zawsze przy tym wyczuwalny jest $\mathrm{u}$ niego konkretny moment historyczny. Tak było w przywoływanych tu utworach, przy czym wpisanie ich wątku fabularnego $\mathrm{w}$ rzeczywisty moment historyczny pozostawia Czechow czytelnikowi. Wymaga to od niego znajomości szerszego kontekstu czasowego, który zapodany jest wystarczająco czytelnie poprzez wskazanie na znane powszechnie wydarzenia, czasem datę, nie zawsze konkretną, jak 
to było np. w Ogniach, lub też poprzez odwołanie się bohatera do jego wspomnień z młodości, jak to ma miejsce również w tym opowiadaniu. W kolejnych utworach, m.in. w Opowiadaniu nieznajomego czlowieka (Рaccka3 неизвестного человека), Studenсіе (Студент), Моіт żусіи (Моя жизнъ), sроtykamy się z takim właśnie postawieniem tej kwestii. Prezentowana jest ona i dyskutowana przez różne postacie, co sprawia, że przyjmuje ten moment zawsze niejednoznaczny charakter. Zrozumiałe wydaje się, że zwykle $\mathrm{w}$ takich sytuacjach pojawiają się wypowiedzi, w których obecne są słowa w rodzaju "filozofować”, „rozważać”, „myśleć" czy zwrot typu „znowu o tym samym", charakterystyczny dla utworów dramatycznych. Jeżeli odniesiemy to do kwestii bytu, to nic dziwnego, że dysputy takie kończą postacie Czechowa bez konkretnego rezultatu.

W poszukiwaniu odpowiedzi na trudne pytania jego bohaterowie odwołują się zwykle do wydarzeń z przeszłości, do swoich doświadczeń; do wydarzeń historycznych czy też zaczerpniętych z Ewangelii i Biblii. Takie powtarzające się sytuacje, zdawałoby się, powinny w końcu zmusić bohaterów Czechowa do zdecydowanych kroków. Te jednak nie następują, co nie znaczy, że nie spotkamy się z próbami pokazania, iż życie człowieka zmieniało się na przestrzeni wieków. Pewien sygnał takiego rozumowania zabrzmiał w Ogniach. W Opowiadaniu nieznanego człowieka, wyraźniej niż $\mathrm{w}$ innych utworach, przejawia się konkretny moment historyczny, zawoalowany wszakże na tyle, aby czytelnik zmuszony został do ustalenia historycznych faktów. Uważny i zorientowany odbiorca odnajdzie w utworze echa związane z działalnością Narodnej woli, której członkiem był kiedyś główny bohater. $\mathrm{W}$ opowiadaniu nie padają daty czy nazwiska, ale portret narodowolca, który kaja się po latach, przyznając się do swoich błędów, jest mocno przekonujący. Zdaje się, że pisarz chciał powiedzieć, iż słuszne z pozoru idee, którym służy pojedynczy człowiek i wyznająca je grupa, mogą, z punktu widzenia biegu historii, okazać się niewłaściwymi, a nawet tragicznymi. Czy w ten sposób pisarz odrzucał podobne działania? W tym przypadku wydaje się, że tak. Wskazywać na to mogą utwory, w których Czechow pokazuje, w co zamieniły się po latach działania ludzi takich jak bohater opowiadania. Ilustrują to utwory typu Dom z facjata (Дом с мезонином) сzу Nowa dacza (Новая дача).

Następnym, dość wyjątkowym przykładem ujęcia biegu dziejów przez pisarza może być opowiadanie Student. Jego bohater to seminarzysta, który przyjechał do rodziców na Święto Zmartwychwstania. Wybór tego momentu w kalendarzu nie jest przypadkowy. W Wielki Piątek młody człowiek błądzi po polach. Głodny i zziębnięty nie przypadkiem zapewne odczuwa zastanawiającą zbieżność tego dnia i miejsca z historią, jaka miała miejsce dawno temu: 
И теперь, пожимаясь от холода, студент думал о том, что точно такой же ветер дул при Рюрике и при Иване Грозном, и при Петре, и что при них была точно такая же лютая бедность, голод, такие же дырявые соломенные крыши, невежество, тоска, такая же пустыня кругом, мрак, чувство гнета, - все эти ужасы были, есть и будут, и оттого, что пройдет еще тысяча лет, жизнь не станет лучше. И ему хотелось домой (П. 8, s.306).

Rozmowa z dwiema kobietami, grzejącymi się przy ognisku, jeszcze bardziej wzmocniła uczucie bliskości tamtej ewangelicznej sytuacji z aktualną: „Ах, какая то была страшная ночь, бабушка!” (s. 307). Kiedy student przypomniał kobietom sąd nad Jezusem, biczowanie i jego śmierć, to odczucia te udzieliły się również im. Wrażenie bliskości tej „strasznej nocy” $\mathrm{z}$ tamtą jest tak silne, że Iwan Wielkopolski całkowicie poddaje mu się. $\mathrm{W}$ jego głowie kłębią się różne myśli - od bardzo smutnych do radosnych. Te drugie, co może zastanawiać, zdają się jednak przeważać. Może to rodzić pytanie, na ile bliskie mogą one być samemu pisarzowi:

И радость вдруг заволновалась в его душе, и он даже остановился на минуту, чтобы перевести дух. Прошлое, думал он, связано с настоящим непрерывною цепью событий, вытекавших одно из другого. И казалось ему, что он только что видел оба конца этой цепи: дотронулся до одного конца, как дрогнул другой (s. 309).

Podobnie mocnego, wyrażonego wprost przekonania o związku przeszłości z teraźniejszością raczej trudno byłoby szukać u pisarza, chociaż będzie się ono przewijało w szeregu innych opowiadań i utworach dramatycznych, włącznie z zamykającymi jego twórczość opowiadaniem Narzeczona (Hеbеста) i sztuką Wiśniowy sad (Вишнеbыü cad). Wiele razy zetkniemy się tam z "prozą życia”, która wydaje się niezmienna, nudna, ale trzeba się z nią godzić, jak ma to miejsce w Wujaszku Wani. Trzeba jednak mieć nadzieję, że za "sto czy dwieście” lat odmieni się życie jednostki. Czechow widział realizację tego marzenia nawet wcześniej, czemu dał wyraz w historii bohaterki opowiadania Narzeczona. Wprawdzie w jego zakończeniu nie mogło zabraknąć „Czechowowskiego powątpiewania” w postaci słów:

Она пошла наверх к себе укладываться, а на другой день утром простилась со своими и, живая, веселая, покинула город - как полагала, навсегда (С. 10, s. 220).

Odnotowywałem nieco wcześniej, że problematyka „bytopisania” u pisarza wymaga szerszego rozważenia. Niech niniejszy tekst będzie tego dowodem, a jego rozwinięcie nastąpi za jakiś czas. Nie można przy tej okazji nie przypomnieć, że nadal aktualne jest przekonanie o „zagadkowości Czechowa", które długo nie mogło przebić się do świadomości krytyki i czytelnika z uwagi na powtarzające się niezbyt trafne twierdzenia typu „kronikarz codzienności" czy bardziej wyrozumiałe, ale ogólnikowe, "głęboki psycholog" oraz „znawca życia rosyjskiej prowincji”. 


\section{Bibliografia}

Gr o s s m a n W., Życie i los, przeł. J. Czech, Warszawa 2011.

K s e n i c z A., Anton Czechow - nieco inaczej o sobie i innych, [w:] tegoż, Stowiański wielogłos, czyli od Antona Czechowa do Jerzego Harasymowicza, Zielona Góra 1999, s. 5-30.

K s e n i c z A., Czechowowskie przemiany wewnętrzne, [w:] tegoż, Ścieżkami bohaterów Antona Czechowa, Zielona Góra 2007, s. 173-192.

А. П. Чехов в воспоминаниях современников, ред. В. Вацуро и др., Москва 1986.

Б у лг а ко в С., Чехов, как мыслитель, Киев 1905.

Г у р в и ч И., Проза Чехова. (Человек и действительность), Москва 1970.

К а т а е в В., Спор о Чехове: конеи или начало?, [w:] Чеховиана. Мелиховские труды и дни, Москва 1995.

П е т р о в Г., Евангелие, как основа жизни, Санкт-Петербург 1900.

С о б е н н и к о в А., Библейский образ в прозе А. П. Чехова (аксиология и поэтика), [w:] О поэтике А. П. Чехова, Сборник научных трудов, ред. кол. Г. Чернышова и др., Изд-во Иркутского университета, Иркутск 1993, s. 24-25.

Ч е х о в А. П., Полное собрание сочинений и писем в тридиати томах. Письма В двенадцуати томах, Москва 1974-1983. 